\title{
PENGARUH EKUITAS MEREK, HARGA DAN LOKASI TERHADAP KEPUTUSAN PEMBELIAN KONSUMEN PADA QUALITY FRIED CHICKEN JALAN ISMALIYAH MEDAN
}

\author{
Kevinli ${ }^{1}$,Pesta Gultom ${ }^{2}$ \\ ${ }^{1,2}$ STIE Eka Prasetya, Medan, Indonesia \\ kevinlie37@gmail.com; Natalin.gultom@yahoo.com
}

\begin{abstract}
This study aims to determine whether brand equity influences the purchasing decision of Quality Fried Chicken, knowing whether the price influences the purchasing decision of Quality Fried Chicken, knowing whether the location influences the purchasing decision of Quality Fried Chicken and knowing whether brand equity, price and location are equally influential towards the purchase decision for Quality Fried Chicken. The research methodology used is descriptive quantitative method. The type of data used in this study is quantitative data, namely data obtained in the form of numbers or numbers. Data source are primary and secondary data. The result of the analysis show that brand equity has a sisnificant and positive influence on Quality Fried Chicken's purchasing decisions the analysis shows that prices have a significant and negative influence on Quality Fried Chicken's purchasing decisions The result of the analysis show that the location has a significant and positive influence on Quality Fried Chicken's purchasing decisions based on the result of the partial hypothesis test. The results showed that brand equity, price dan location had a significant effect on the Quality Fried Chicken purchasing decision While the remaining is influenced by other variables not examined, such as promotion, service quality, product quality and other thing not discussed in this study.
\end{abstract}

Keywords : Brand Equity, Price, Locationy and Purchasing Decision

\begin{abstract}
ABSTRAK
Penelitian ini bertujuan untuk mengetahui apakah ekuitas merek berpengaruh terhadap keputusan pembelian Quality Fried Chicken, mengetahui apakah harga berpengaruh terhadap keputusan pembelian Quality Fried Chicken, mengetahui apakah lokasi berpengaruh terhadap keputusan pembelian Quality Fried Chicken dan mengetahui apakah ekuitas merek, harga dan lokasi sama-sama berpengaruh terhadap keputusan pembelian Quality Fried Chicken. Metodologi penelitian yang digunakan adalah metode deskriptif kuantitatif. Jenis data yang digunakan dalam
\end{abstract}


penelitian ini adalah data kuantitatif, yaitu data yang diperoleh dalam bentuk angka atau bilangan. Sumber data berupa data primer dan sekunder. Data dianalisis dengan menggunakan metode analisis regresi linear berganda. Hasil analisis penelitian menunjukkan bahwa ekuitas merek memiliki pengaruh signifikan dan positif terhadap keputusan pembelian Quality Fried Chiken Hasil analisis menunjukkan harga memiliki pengaruh signifikan dan negatif terhadap keputusan pembelian Quality Fried Chiken. Hasil analisis menunjukkan lokasi memiliki pengaruh signifikan dan positif terhadap keputusan pembelian Quality Fried Chiken. Hasil penelitian menunjukkan bahwa ekuitas merek, harga dan lokasi berpengaruh signifikan terhadap keputusan pembelian Quality Fried Chiken artinya bahwa ekuitas merek, harga dan lokasi secara simultan mempunyai pengaruh keputusan pembelian. Sedangkan sisanya dipengaruhi oleh variabel lain yang tidak diteliti, seperti promosi, kualitas layanan dan kualitas produk yang tidak dibahas dalam penelitian ini..

Kata Kunci : Ekuitas Merek. Harga, Lokasi dan Keputusan Pembelian

\section{PENDAHULUAN}

Waralaba yang memiliki potensi penghasilan yang tinggi di Indonesia sekarang ini tentunya adalah waralaba restoran cepat saji karena jumlah pertumbuhan penduduk Indonesia yang dapat dikatakan tinggi dan ketersediaan makanan cepat saji semakin dibutuhkan sejalan dengan perkembangan jaman yang modern ini. Peningkatan kegiatan di bidang pemasaran harus dilaksanakan secara terencana. Atau dengan kata lain, perusahaan harus menentukan strategi pemasaran yang tepat. Perubahan lingkungan perusahaan terutama faktor pesaing yang mampu menghasilkan produk yang sama, menyebabkan banyak perusahaan berorientasi pada konsumen. Perusahaan yang berorientasi pada konsumen hendaknya selalu memikirkan apa yang dibutuhkan oleh konsumen, apa yang diinginkan konsumen, dan harga jual yang bagaimana yang disenangi oleh konsumen sehingga konsumen tidak hanya puas, akan tetapi menjadi loyal dan kembali membeli produk yang dijual.

Quality merupakan sebuah usaha yang bergerak dibidang makanan dimana menu utama dari produknya adalah berasal dari daging ayam yang digoreng dan kemudian dipadukan dengan menu-menu lain yang ada. Quality sendiri mirip dengan SS Fried Chicken, QQ Fried Chicken, dan Hisana Fried Chicken dimana sama-sama bergerak dalam bidang makanan yaitu ayam goreng. Karena banyaknya perusahaan yang bergerak dibidang tersebut maka keputusan pembelian konsumen sangat diperebutkan untuk meningkatkan penghasilan dari setiap perusahaan dimana keputusan pembelian konsumen adalah preferensi konsumen atas merekmerek yang ada di dalam kumpulan pilihan dan niat konsumen untuk membeli merek yang paling disukai (Kotler, 2013).

Merek sangat penting bagi suatu perusahaan karena perusahaan dituntut bersaing secara komprtitif dalam hal menciptakan dan mempertahankan konsumen loyal salah satunya 
adalah perang antar merek. Maka sebuah perusahaan harus dapat menciptakan ekuitas merek perusahaannya sendiri karena ekuitas merek adalah nilai tambah yang diberikan pada produk atau jasa dimana nilai ini dapat dicerminkan dalam cara berpikir, merasa dan bertindak terhadap merek, harga, pangsa pasar, dan profitabilitas yang dimiliki perusahaan (Kotler dan keller, 2012). Dengan adanya suatu ekuitas merek yang baik maka suatu perusahaan akan senantiasa mengalami peningkatan dalam hal memperjual belikan produk yang diproduksi seperti halnya pada penjualan Quality Fried Chicken.

Bukan hanya dari faktor ekuitas merek saja sebuah usaha dapat berkembang dan mendapatkan keuntungan, tetapi harga dan lokasi juga berperan penting bagi kelangsungan keputusan pembelian konsumen karena harga adalah nilai suatu barang atau jasa yang diukur dengan sejumlah uang. Berdasarkan nilai tersebut seseorang atau perusahaan bersedia melepas barang atau jasa yang dimiliki kepada orang lain (Kotler, 2013) sehingga harga dapat dikatakan sebagai sebuah faktor penting dalam proses pemasaran produk karena dengan harga yang terjangkaulah maka konsumen akan membelinya. Tetapi disamping itu menurut Walton (2014:17) harga dan kualitas pelayanan memiliki pengaruh yang tinggi terhadap kepuasan konsumen. Hal ini sering tidak diperhatikan oleh beberapa perusahaan sehingga konsumen akan berpikir lagi untuk membeli produk tersebut dengan harga yang dapat dikatakan rendah dan akan merasa tidak puas saat menggunakan produk tersebut. Penetapan harga adalah salah satu permasalahan yang paling utama dihadapi oleh sebuah perusahaan karena jika penetapan harga terlalu rendah dengan tujuan untuk menarik keputusan pembelian konsumen maka itu dapat merupakan sebuah ancaman bagi perusahaan tersebut karena sebagian orang akan berpikir kalau harga yang murah maka produk tersebut kurang bagus dan lainnya tetapi sebaliknya ada beberapa orang yang datang membeli suatu produk dikarenakan harganya yang terjangkau.

\section{KAJIAN LITERATUR}

Menurut Kotler dan Keller (2012:251-252) keputusan pembelian adalah suatu proses penyelesaian masalah yang terdiri dari menganalisa atau pengenalan kebutuhan keinginan, pencarian informasi, penilaian sumber-sumber seleksi terhadap alternative pembelian, keputusan pembelian, dan perilaku setelah pembelian dimana menurut Kothler dan Keller ada 4 indikator Keputusan Pembelian yang terdiri dari : 1) Kemantapan pada sebuah produk. 2) Kebiasaan dalam membeli produk. 3) Memberikan rekomendasi kepada orang lain. 4) Melakukan pembelian ulang.

Menurut Durianto (2014:4), ekuitas merek adalah seperangkat asset dan liabilitas merek yang terkait dengan suatu merek, nama, symbol yang mampu menambah atau mengurangi nilai yang diberikan oleh sebuah produk atau jasa baik pada perusahaan maupun pada pelanggan. Dan menurut Durianto ada 4 indikator untuk ekuitas merek antara lain : 1) Kesadaran Merek. 2) Asosiasi Merek. 3) Persepsi Kualitas. 4) Loyalitas Merek.

Menurut Kotler dan Armstrong (2012:345) harga merupakan sejumlah uang yang ditagihkan atas suatu produk atau jasa, atau jumlah nilai yang ditukarkan para pelanggan untuk memperoleh manfaat dari memiliki atau menggunakan suatu produk atau jasa. Dan menurut Kotler dan Armstrong ada 5 indikator harga antara lain : 1) Daftar Harga. 2)Diskon. 3) Syarat Pembayaran. 4) Kredit. 5) Periode Pembayaran. 
Menurut Lupiyoadi (2013:157) lokasi adalah keputusan yang dibuat perusahaan berkaitan dengan di mana operasi dan stafnya akan ditempatkan. Dan menurut Lupiyoadi ada 4 indikator lokasi antara lain : 1) Strategi Pemasaran. 2) Analisis Regional. 3) Analisis Area 4) Evaluasi Tempat.

\section{METODE PENELITIAN}

Lokasi penelitian ini adalah pada Quality Fried Chicken Jalan Ismaliyah Medan. Dalam penelitian ini, populasi yang digunakan adalah konsumen pada Quality Fried Chicken Jalan Ismaliyah Medan sebanyak 900 konsumen. Berdasarkan perhitungan dengan menggunakan rumus Slovin diperoleh sampel dalam penelitian ini sebanyak 276 responden. Dalam memperoleh data dan informasi yang sesuai dengan penelitian ini maka peneliti menggunakan kuesioner (angket) yang diberikan secara langsung kepada responden untuk mengumpulkan data dan informasi yang terkait dengan penelitian ini dimana menurut Sugiyono (2017:121) angket merupakan pengumpulan data dengan mengajukan daftar pertanyaan tertulis tentang masalah yang akan dibahas.

Dalam penelitian ini peneliti menggunakan analisis regresi linear berganda dimana berkaitan dengan studi mengenai ketergantungan variable dependen dengan variable independen, dengan tujuan untuk mengetahui dan memprediksi rata-rata populasi atau nilai rata-rata variable dependen berdasarkan nilai independen yang diketahui. Analisis linear berganda disini digunakan untuk mengetahui pengaruh Ekuitas Merek(X1), Harga(X2) dan Lokasi(X3) terhadap Keputusan Pembelian(Y) konsumen pada Quality Fried Chiclen. Rumus analisis regresi linear berganda yang diperoleh dari penelitian ini adalah :

$$
\mathrm{Y}=\mathrm{a}+\beta 1 \mathrm{X} 1-\beta 2 \mathrm{X} 2+\beta 3 \mathrm{X} 3+\mathrm{e}
$$

Keterangan :

$\mathrm{Y}=$ Keputusan Pembelian

$\mathrm{X} 1=$ Ekuitas Merek

$\mathrm{X} 2$ = Harga

$\mathrm{X} 3=$ Lokasi

$\beta 1, \beta 2, \beta 3=$ Koefisien regresi variable independen.

$\mathrm{e}=$ Kesalahan penduga $($ yang tidak terungkap $=5 \%)$

\section{HASIL DAN PEMBAHASAN}

Menurut Sugiyono (2017:134) Uji Validitas adalah pengujian yang dilakukan pada tiap butir digunakan analisis item, yaitu mengkorelasikan skor tiap butir dengan skor total yang merupakan jumlah tiap skor, dimana syarat minimum untuk dianggap valid adalah jika tiap butir skor memenuhi $r=0,3$ sehingga jika tiap butir skor total kurang dari 0,3 maka butir dalam nstrumen tersebut dinyatakan tidak valid. Sedangkan Uji Reliabilitas menurut Sugiyono (2017:136) adalah alat untuk mengukur suatu kuesioner yang merupakan indicator dari variable atau konstruk, dimana syarat untuk dikatakan realibel jika tiap variable memberikan 
Cronbach Alpha yang lebih besar dari 0,6. Hasil Uji Validitas dan Uji Reliabilitas akan disajikan pada Tabel 1 dan Tabel 2.

Tabel 1. Hasil Uji Validitas

\begin{tabular}{cccc}
\hline No & Pernyataan & Variabel & rhitung \\
\hline 1 & EM-1 & & 0,839 \\
2 & EM-2 & Ekuitas & 0,723 \\
3 & EM-3 & Merek & 0,648 \\
4 & EM-4 & & 0,653 \\
\hline 1 & H-1 & & 0,667 \\
2 & H-2 & & 0,841 \\
3 & H-3 & Harga & 0,431 \\
4 & H-4 & & 0,784 \\
\hline 1 & L-1 & & 0,869 \\
2 & L-2 & Lokasi & 0,739 \\
3 & L-3 & & 0,657 \\
4 & L-4 & & 0,538 \\
\hline 1 & KP-1 & & 0,878 \\
2 & KP-2 & Keputusan & 0,877 \\
3 & KP-3 & Pembelian & 0,739 \\
4 & KP-4 & & 0,567 \\
\hline
\end{tabular}

Dari hasil Tabel 1 diperoleh nilai rhitung dari masing-masing item pernyataan untuk setiap variable diperoleh di atas 0,3 sehingga dapat dikatakan pernyataan yang digunakan dalam variable penelitian dikatakan validitas(valid).

Tabel 2. Hasil Uji Reliabilitas

\begin{tabular}{cccc}
\hline No & Variabel & $\begin{array}{c}\text { Jumlah } \\
\text { Item }\end{array}$ & $\begin{array}{c}\text { Cronbac } \\
\text { h's } \\
\text { Alpha }\end{array}$ \\
\hline 1 & $\begin{array}{c}\text { Ekuitas } \\
\text { Merek }\end{array}$ & 4 & 0,679
\end{tabular}




$\begin{array}{cccc}2 & \text { Harga } & 4 & 0,616 \\ 3 & \text { Lokasi } & 4 & 0,652 \\ & \begin{array}{l}\text { Keputusn } \\ \text { Pembelian }\end{array} & 4 & 0,739\end{array}$

Dan dari Tabel 2 juga diperoleh dari masing-masing variable Cronbach's Alpha nya tidak dibawah 0,6 sehingga dapat dikatakan relalibel. Distribusi kumulatif dari distribusi normal.

\section{Uji Asumsi Klasik}

\section{Uji Normalitas}

Uji Normalitas bertujuan untuk menguji apakah dalam model regresi, variable terikat dan variable bebas keduanya mempunyai distribusi normal ataukah tidak. Ada du acara untuk mendeteksi apakah residual berdistribusi normal atau tidak, yaitu dengan analisis grafik dan uji statistik. Analisis grafik dapat dilihat pada Gambar 2. Grafik Histogram dan Gambar 3. Grafik Normal P-Plot.

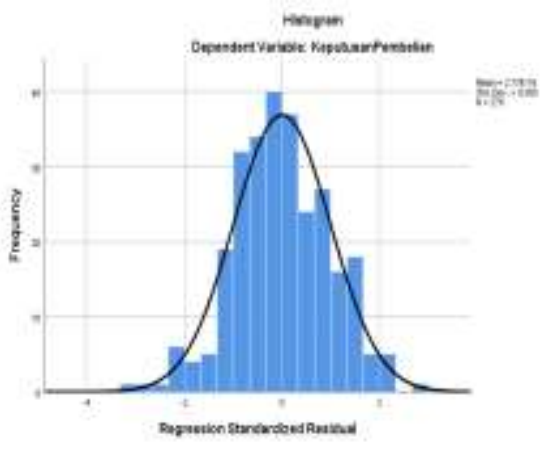

Gambar 2. Grafik Histogram

Dari gambar 2 dapat dilihat bahwa grafik histogram yang dihasilkan membentuk kurva yang cenderung simetri dan tidak lebih kekiri dan tidak lebih kekanan sehingga dapat dikatakan data berdistribusi normal. 


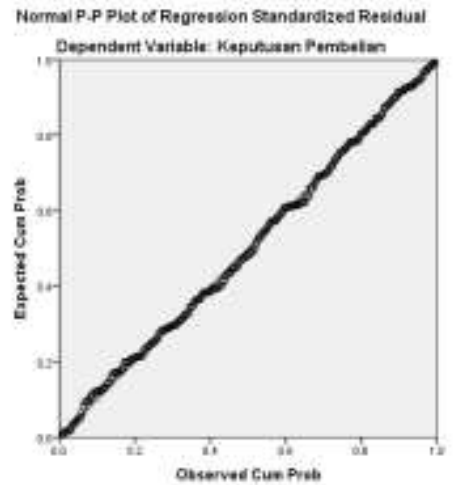

Gambar 3 Grafik Normal P-Plot

Dari gambar 3 menunjukkan bahwa data (titik) menyebar disekitar garis diagonal dan mengikuti arah garis diagonal sehingga dapat dikatakan data dari Normal Probability Plot menunjukkan pola distribusi normal.

Tabel 3. Uji Statistik Untuk Normalitas

\begin{tabular}{|c|c|c|}
\hline One-Sample & nogorov Smirt & $\begin{array}{l}\text { Test } \\
\text { Unstandardize } \\
\text { d Residual }\end{array}$ \\
\hline $\mathbf{N}$ & & 276 \\
\hline \multirow[t]{2}{*}{ 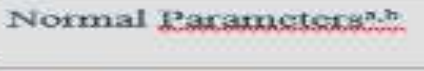 } & Meian & .0000000 \\
\hline & Std-Deviation & 1.83118788 \\
\hline Mast Extremac & Absolute & .030 \\
\hline \multirow[t]{2}{*}{ Difforences } & Positive & 030 \\
\hline & Negative & -027 \\
\hline Test Statistic & & .030 \\
\hline Ausuculp. Sig. (2-tatiled) & & $.200^{c-d}$ \\
\hline
\end{tabular}

Dari Tabel 3 di atas, maka dapat diketahui nilai signifikan lebih besar dari 0,05 yaitu sebesar 0,200 dimana hasil pengujian ini menunjukkan bahwa data berdistribusi normal.

\section{Hasil Analisis Regresi Linear Berganda}


Tabel 5. Standardized Coefficients

\begin{tabular}{|c|c|c|c|c|c|c|}
\hline \multirow[b]{3}{*}{ Model } & \multicolumn{6}{|c|}{$\begin{array}{c}\text { Hasil Persamaan Regresi Linear Berganda } \\
\text { Coefficients }{ }^{a}\end{array}$} \\
\hline & & \multicolumn{2}{|c|}{ Unstandardized Coefficients } & \multirow{2}{*}{$\begin{array}{c}\text { Standardized } \\
\text { Coefficients } \\
\text { Beta }\end{array}$} & \multirow[b]{2}{*}{$t$} & \multirow[b]{2}{*}{ Sig. } \\
\hline & & B & Std. Error & & & \\
\hline 1 & (Constant) & 11.000 & 1.258 & & 8.747 & .000 \\
\hline & EkuitasMerek & .210 & .044 & .252 & 4.817 & .000 \\
\hline & Harga & -.300 & .062 & -.251 & -4.812 & .000 \\
\hline & Lokasi & .356 & .051 & 365 & 6.975 & .000 \\
\hline
\end{tabular}

Keputusan Pembelian $=11,000+$ 0,210 Ekuitas Merek $-0,300$ Harga + 0,356 Lokasi $+\mathrm{e}$

Penjelasan persamaan sebagai berikut:

a. Konstanta sebesar 11,000 menyatakan bahwa jika variabel independen dianggap konstan, maka nilai keputusan pembelian sebesar 11,000.

b. Variabel ekuitas merek mempunyai nilai koefisien regresi sebesar 0,210 dan bertanda positif artinya setiap kenaikan ekuitas merek sebesar satu mengakibatkan kenaikan keputusan pembelian sebesar 0,210 .

c. Variabel harga mempunyai nilai koefisien regresi sebesar 0,300 dan bertanda negatif artinya setiap kenaikan harga sebesar satu mengakibatkan penurunan keputusan pembelian sebesar 0,300.

d. Variabel lokasi mempunyai nilai koefisien regresi sebesar 0,356 dan bertanda positif artinya setiap kenaikan lokasi sebesar satu mengakibatkan kenaikan keputusan pembelian sebesar 0,356.

\section{Uji t (Uji Parsial)}

Uji t ini dimaksud untuk mengutahui pengaruh secara parsial variable-variabel independen yaitu ekuitas merek, harga dan lokasi terhadap variable dependen yaitu keputusan pembelian atau menguji signifikansi konstanta dan variable dependen. Bentuk pengujiannya adalah sebagai berikut:

1. H0: $\beta 1, \beta 2, \beta 3=0$ artinya ekuitas merek, harga dan lokasi secara parsial tidak berpengaruh terhadap keputusan pembelian Quality Fried Chiken.

2. H1: $\beta 1, \beta 2, \beta 3 \neq 0$ artinya ekuitas merek, harga dan lokasi secara parsial berpengaruh terhadap keputusan pembelian Quality Fried Chiken.

Hasil perhitungan uji t secara parsial diperoleh nilai thitung ekuitas merek sebesar 4,817 dengan nilai signifikan sebesar 0,000. Nilai thitung > ttabel atau 4,817 > 1,96872 maka H0 ditolak atau Ha diterima artinya secara parsial ekuitas merek berpengaruh positif signifikan terhadap keputusan pembelian Quality Fried Chiken. Hasil perhitungan uji t secara parsial diperoleh nilai thitung harga sebesar $-4,812$ dengan nilai signifikan sebesar 0,000. Nilai thitung <-ttabel atau -4,812<-1,96872 maka H0 ditolak atau Ha diterima artinya harga secara 
parsial berpengaruh negatif signifikan terhadap keputusan pembelian Quality Fried Chiken. Hasil perhitungan uji t secara parsial diperoleh nilai thitung lokasi sebesar 6,975 dengan nilai signifikan sebesar 0,000. Nilai thitung > ttabel atau 6,975 > 1,96872 maka H0 ditolak atau Ha diterima artinya secara parsial lokasi berpengaruh positif signifikan terhadap keputusan pembelian Quality Fried Chiken

\section{SIMPULAN}

Kesimpulan dalam penelitian ini adalah:

1. Hasil penelitian ini menyatakan pengaruh Ekuitas Merek $\left(\mathrm{X}_{1}\right)$, Harga $\left(\mathrm{X}_{2}\right)$, dan Lokasi $\left(\mathrm{X}_{3}\right)$ terhadap Keputusan Pembelian $(\mathrm{Y})$ ditunjukkan dari hasil analisis regresi linear berganda dimana Keputusan Pembelian $=11,000+0,210$ Ekuitas Merek - 0,300 Harga $+0,356$ Lokasi $+\mathrm{e}$

2. Hasil Uji t menunjukkan bahwa Ekuitas Merek secara parsial memiliki pengaruh positif dan signifikan terhadap keputusan pembelian Quality Fried Chiken dengan nilai $t_{\text {hitung }}>$ $\mathrm{t}_{\text {tabel }}$ atau 4,817> 1,96872 serta nilai signifikan di bawah 0,05 .

3. Hasil Uji t menunjukkan bahwa Harga secara parsial memiliki pengaruh negatif dan signifikan terhadap keputusan pembelian Quality Fried Chiken dengan nilai - $\mathrm{t}_{\text {hitung }}<-\mathrm{t}_{\text {tabel }}$ atau $-4,812<1,96872$ serta nilai signifikan di bawah 0,05 .

4. Hasil Uji t menunjukkan Lokasi secara parsial memiliki pengaruh positif dan signifikan terhadap keputusan pembelian Quality Fried Chiken dengan nilai $t_{\text {hitung }}>t_{\text {tabel }}$ atau 6,975 $>1,96872$ serta nilai signifikan di bawah 0,05.

5. Hasil Uji F menunjukkan bahwa Ekuitas Merek, Harga dan Lokasi secara serempak berpengaruh terhadap keputusan pembelian Quality Fried Chiken dengan $F_{\text {hitung }}$ 31,518 > $F_{\text {tabel }}$ 2,64 serta nilai signifikansi dibawah 0,05.

6. Berdasarkan nilai koefisien determinasi $\left(\mathrm{R}^{2}\right)$ diketahui bahwa sebesar $25 \%$ keputusan pembelian yang dapat dijelaskan oleh variasi dari tiga variabel independen yang digunakan, yaitu ekuitas merek, harga dan lokasi. Sedangkan sisanya sebesar 75\% dipengaruhi oleh sebab-sebab lain di luar model penelitian

\section{DAFTAR PUSTAKA}

Assauri, S. 2014. Manajemen Pemasaran. Jakarta: Rajawali Pers.

Durianto, Darmadi, Sugiarto dan Tony Sitinjak 2014. Strategi Menaklukan Pasar Melalui Riset Ekuitas dan Perilaku Merek. Jakarta: PT Gramedia Pustaka Utama.

Fadil, Zaki dan Utama, Priyo. 2015. Teknik Marketing Itu Mudah. Yogyakarta: Second Hope

Ferrinadewi, Erna. 2008. Merek dan Psikologi Konsumen. Yogyakarta: Graha. Ilmu.

Ghozali, Imam. 2016. Aplikasi Analisis Multivariate Dengan Program SPSS. Semarang: Badan Penerbit Universitas Diponegoro.

Hasan, A. 2013. Marketing Dan Kasus-kasus Pilihan. Jakarta: PT Buku Seru. 
Kasmir. 2011. Manajemen Perbankan. Jakarta:Rajagrafindo Persada

Kotler Phillip, Kevin Lance Keller. 2012. Marketing Management. 14th edition. Jakarta:PT. Indeks Kelompok Gramedia.

Kotler, Philip, dan Gary Armstrong 2012. Prinsip-prinsip Pemasaran. Edisi 13. Jilid 1. Erlangga : Jakarta.

Kotler, Phillip. 2013. Manajemen Pemasaran. Jakarta; Erlangga.

Kurniawan, Arief Rakhman. 2014. Total Marketing. Jakarta: PT Buku Kita.

Lupiyoadi, Rambat dan A Hamdani. 2006. Manajemen Pemasaran Jasa. Edisi 2. Jakarta: Salemba Empat

Lupiyoadi, Rambat. 2013. Manajemen Pemasaran Jasa Berbasis Kompetensi. Edisi 3. Jakarta: Salemba Empat.

Sanusi, Anwar. 2014. Metodologi Penelitian Bisnis : Disertai Contoh Proposal Penelitian Bidang Ilmu Ekonomi Dan Manajemen. Jakarta: Salemba Empat.

Simamora, Bilson. 2011. Memenangkan Pasar dengan Pemasaran Efektif dan Profitabel. Jakarta: PT. Gramedia Pustaka Utama.

Sudaryono. 2016. Manajemen Pemasaran Teori \& Implementasi. Yogyakarta: CV. Andi Offset.

Sugiyono. 2017. Metode Penelitian Kuantitatif Kualitatif Dan R\&D. Bandung : PT Alfabeta.

Suharno dan Yudi Sutarso. 2010. Marketing In Practice. Yogyakarta: Graha Ilmu.

Sunyoto, Danang. 2013. Kewirausahaan Untuk Kesehatan. Yogyakarta: Nuha Medika.

Sunyoto, Danang. 2014.Konsep Dasar Riset Pemasaran \& Perilaku Konsumen. Yogyakarta : CAPS.

Tjiptono, F. 2011. Manajemen dan Strategi Merek, Seri Manajemen Merek. Yogyakarta: Penerbit Andi Offset.

Tjiptono, F. 2014, Pemasaran Jasa - Prinsip, Penerapan, dan Penelitian.Yogyakarta: Andi Offset.

Tjiptono, F.. 2015. Strategi Pemasaran, Edisi 4, Yogyakarta: Penerbit Andi.

Utami, Christina W. 2012. Manajemen Ritel. Edisi Kedua. Jakarta: Salemba Empat.

Walton, 2014. The Brave New World of Neuromarketing is Here. B\&I. Australia, 19 November. 